\title{
ASEAN Socio-Cultural Community: ASEAN Approach and Effort in Rural Development and Poverty Eradication
}

\author{
Fujica Anak Anggo ${ }^{l, *}$ and Louis Laja ${ }^{1}$ \\ ${ }^{1}$ Institute of Design and Innovation, University Malaysia Sarawak, Malaysia
}

\begin{abstract}
This paper examines the ASEAN Community approach and effort towards rural development and poverty eradication. The research by ASEAN Socio-Cultural Community which highlighted rural development and poverty eradication was driven by many factors. What has ASEAN planned to reduce poverty and increase rural development? Is this plan realistic? What approach was used? The World Bank defined rural development as a strategy designed to improve the economic and social life of a specific group of people; the rural poor. It involves extending the benefits of development to the poor among those who seek a livelihood in rural areas. "Human capital development should not be neglected as well as it can be the main engine of growth. We must leverage the existing human capital resources towards a holistic approach to rural development" (Bernama, 2017). In addition, according to Malaysia's former Deputy Prime Minister, Datuk Seri Dr. Zahid Hamidi, poverty eradication not only continues to be a priority in the ASEAN region as stated in ASEAN Socio-cultural Community Blueprints 2025 but also globally as outlined in the United Nations 2030 Agenda for Sustainable Development. This study will explain broadly what ASEAN Socio Cultural Community is building towards rural development and poverty eradication by its notion of people centricity. ${ }^{1}$
\end{abstract}

Keywords: rural development, planning, and poverty eradication

\section{Introduction}

ASEAN Community consists of three pillars: ASEAN Political Security Community, ASEAN Economic Community and ASEAN Socio-Cultural Community. ASEAN Political Security Community (APSC) aims to bring ASEAN's political and security relations to a higher plane. The second is ASEAN Economic Community (AEC), whose goal is of regional economic integration. The AEC intends to narrow the development gap among the member states and transform the region into a stable and prosperous community. The ASEAN Socio-Cultural Community (ASCC) intends to contribute to realizing an ASEAN Community that is people centric and socially responsible with a view of achieving enduring solidarity and unity among the nations and people of ASEAN by forging a common identity in building a caring and sharing society which is inclusive and harmonious where the well-being, livelihood and welfare of the people is enhanced (Amador, 2011). A short brief on ASEAN Socio Cultural Community - ASCC in consonance with the goal set by ASEAN Vision 2020, envisages a Southeast Asia bonded together in partnership as a community of caring societies. In line with the programs of action plan set by the 1976 Declaration of ASEAN Concord, the community shall foster cooperation in social development aimed at raising the standard of living of disadvantaged groups and the rural population, and shall seek the active involvement of all sectors of society, in particular the women, youths and local societies (Rodolfo, 2006).

Standing on fundamental premises and taking a long term perspective, one would say that the core of the ASEAN Community is the Socio-Cultural Community conceived as a vehicle for developing a sense of Southeast Asian identity, building a regional awareness and fostering mutual understanding among the people of ASEAN (Severino, 2006). The 10 countries of ASEAN have decided the right planning that benefits and engages the people. They cooperate to help each other to face arising issues. Moreover, when ASEAN Community was launched in 2015 it was a historic milestone and was seen as a culmination of ASEAN resilience and dynamism throughout a journey lasting nearly half a century, and gave a signal to the world of how far and how well the ASEAN Member States have achieved in coming together as one community (ASEAN Community, 2015). According to ASEAN Socio-Cultural Community Blueprint 2025, The ACSS 2025 opens a world of opportunities to collectively deliver and fully realize human development, resilience and sustainable development to face new emerging challenges together. Furthermore, ASEAN has developed an ASEAN Socio-Cultural Community Blueprint 2025 in order to lift the quality of life of its peoples through cooperative activities that are people-oriented, people centric, environmentally friendly, and geared towards the promotion of sustainable development to face the new and emerging challenges in ASEAN (ASEAN Socio-Cultural Community Blueprint 2025). By discussing the notion of ASEAN that is people -oriented and people centric, this paper provides important insights into understanding rural development and poverty eradication more deeply.

*Corresponding author: fujian_anggo@yahoo.com 


\section{Literature Review}

Theoretically, sustainable development should be pursued in a coherent manner at global, regional, sub-national level, with nested objectives based on subsidiarity principal coordinated vertically (top-down and bottom-up) (Simon, 2015). Highlighting one of the ASEAN visions stated in ASCC Blueprint 2025, sustainability is defined as development that satisfies the needs of the present without compromising the capacity of future generations, guaranteeing the balance between economic growth, care for the environment and social wellbeing (Acciona, n.d).

As for the first approach, ASEAN countries are, according to United Nations.org, on September $25^{\text {th }} 2015$, countries that adopted a set of goals to end poverty, protect the planet and ensure prosperity for all as part of a new sustainable development agenda. There are 17 goals to transform the world - no poverty, zero hunger, good health and wellbeing, quality education, gender equality, clean water and sanitation, affordable and clean energy, decent work and economic growth, reduced inequality, sustainable cities and communities, responsible consumption and production, climate action, life below water, life on land, peace justice, strong institution and lastly, partnership for the goals. All 17 goals have been planned and are well aligned with the current and future needs of an ASEAN community. It is a practical agenda that works towards the goal of 2025. It is the main core of the planning to develop rural development as well as eradicate poverty.

Moreover, according to the Association of Southeast Asian Nation, inclusiveness of sustainable development through the promotion of rural development is a key strategy for ASEAN to eradicate poverty. The aim is to strive for an ASEAN community with equitable access to sustainable environment that can support its social development and its capacity to work towards sustainable environment. All ASEAN communities are free to access this accommodation and government planning equally in a way to increase the quality level of its social development. The social development among its people will impact the environment which will slowly head towards sustainable development goals in 2025 .

There are several key result areas in sustainable environment that are lined up by ASEAN, Conservation and Sustainable Management of Biodiversity and Natural Disaster, Environmentally Sustainable Cities, Sustainable Climate and Sustainable Consumption and Production. All the strategic measures in each of the key result are aligned with the effort that leads to the 17 goals. These are huge effort that ASEAN community had planned, by putting their people first above all. Since ASEAN motto is one vision, one identity and one community, everyone is inclusive in ASEAN development planning. This will promote equitable access to opportunities for people. In summary, without looking at the level of income, skin colour, education level and etc., everyone will be treated equally and can become part of the ASEAN planning. Interestingly, its characteristic focuses on addressing the concerns of all people. It will reduce barriers, have equitable access for all, promotion and protection of human rights. The people is the main core of succession. One community, by putting the people as the main core of the succession plan will not take long to achieve goals. With this, the rural development will be implemented well according to plan since everyone is cooperative.

Resilience is part of the element in ASEAN Socio-Cultural Community Blueprint 2025. It is necessary to build resilient communities in the ASEAN region post-2015. Based on ASCC Blueprint 2025, resilience is an essential aspect of human security, and sustainable environment which is addressed by integrating policies, capacity and institution-building, stakeholder partnerships in disaster risk reduction, humanitarian assistance, and community empowerment among others. Resilience has to be inclusive, non-discriminatory and incorporate market, and technology based policies, including contribution from private sectors as well as the scientific and academic communities. Resilient community is able to withstand quickly from difficult conditions that happen in particular country. So this stability leads to massive growth in the economic, political and social areas in ASEAN. "The ASEAN experiences have shown that when countries in a region consult and cooperate, their chances of stability and success are greater. It is no accident that the ASEAN countries have such good records of economic growth and political stability" mentioned in a speech by the Malaysia Prime Minister, Tun Dr. Mahathir bin Mohamad at the $24^{\text {th }}$ ASEAN Ministerial Meeting in Kuala Lumpur, Malaysia on July 19, 1991. In Malaysia, the head leading the people become the liaison for the government to increase the quality of life for people in the rural areas. For example, in Kuching, Sarawak the people representative who has been voted and trusted by the people in a particular area will install electricity, increase the number of schools in the rural area, help excellent students to further their studies and help give seeds to those involved in agricultural activities. These are the efforts that are given by the government in rural areas for poverty eradication.

Agriculture is a great effort outlined by the government to increase the standard of living. For example, in Indonesia the government stresses on the efforts to grow agricultural industries in order to help its people and reduce poverty especially in rural areas. Renewed efforts towards agricultural and rural growth will be crucial to reduce the number of poor and food-insecure Indonesians. Rapid agriculture growth was a major contributor to the drastic reduction in poverty in the 1980s. In 2002 agriculture (wages and farming incomes) accounted directly for $43 \%$ of rural household income in two thirds of rural employment (ADB, 2006). Moving to Cambodia, according to Mr.Srun Sokhum, Deputy General 
Directorate of Agriculture, Forestry and Fisheries, his country still considers agricultural sector as its main sector that contributes to economic growth, rural poverty reduction and food security. It is important as Cambodia has the highest number of farmers in Southeast Asia. In Lao-PDR, they addressed the issue of food-security not only in Lao but also in Southeast Asia where they highlighted the role of smallholder farmers in agriculture. According to the World Bank, Malaysia has had an inclusive economic growth rate of about 7 percent annually for the past 25 years. Since this growth has been inclusive, Malaysia has been successful at nearly eradicating poverty in the country (Paramasivm, 2018).

\section{Methodology}

It is significant to conduct an investigation to clarify the research information and data obtained. The most suitable methods used for this research is qualitative in nature. The two types of qualitative methods used for this study are observations and documentary analysis of publications that are published by the ASEAN organizations. The reason for choosing observation method is because it is a straightforward way to know what ASEAN people do under certain circumstances. The reason for choosing a documentary analysis method is to obtain data from existing documents without having to question people through interviews and questionnaires.

\subsection{Observation Method}

The observation is conducted to observe the behaviour of people towards the changes that were made by the government. Observation is a systematic data collection approach. Researchers use all their senses to examine people in natural settings or natural occurring situations (Foundation, 2008). Observations are conducted at places that has less access to facilities like clean water, electricity, less development and etc. Investigation was done at the place that has a bit of development done by the government to see the changes that shape the lives of people in that particular place. As the name describes, "observational" methods are all about observing the participants. The observation will help to understand the research better by looking into pre and post development in the area. For example, the government has given fruit seeds to people in rural areas in Sarawak to support the agricultural initiative. After two years of implementation, some people in the rural area have become entrepreneurs and they can afford to buy basic things. Observed behaviour will be recorded and analysed to match the research goals.

\subsection{Documentary-Analysis}

The documentary-analysis is conducted to analyse the source that is being published by the ASEAN countries to investigate deeply the planning and effort made that need to be implemented. The document can be found at the State Library, internet and some government offices. Document analysis is a form of qualitative research in which the document is interpreted by the researcher to give voice and meaning around assessment topic. It describes the nature and form of the document, outline the advantages, and limitation of document analysis, and offers specific examples of usage of documents in the research process (Bowen, 2009). The publications can be found via the internet through the particular website. For example, the ASEAN official portal is where all the publications can be found in the website and workshop proceedings. It is a genuine source which is up to date and suits the analysis process as well. Analysing documents incorporates coding content into themes like how a focus group or interview transcript are analysed (Bowen, et al. 2009). The types of documents used for this research was newspaper articles, journal articles, government policy, etc. The relevant source is taken and analysed to support the data, evidence, and information.

\section{Results and Findings}

To answer the main purpose of the research, the results were obtained. The research and the methodology method were aligned with the study. There is significant planning that ASEAN has outlined to make ASEAN a better region, peaceful, harmonious, with zero poverty and increase development in the rural areas. It is implemented to suit with the current situation and event that occur in that particular countries. How many years would it take to settle the problem? The answer is, it depends. ASEAN team members did cooperate actively and respond to the issues that were raised. The evidence is Laos, Cambodia, Myanmar, Indonesia and more are participating actively in agricultural sectors by organizing Agricultural Workshop Proceeding which is held at each country. The agricultural sector has highly impacted the quality of people's life. Many European countries are confident enough to cooperate not only to expand their businesses but also to invest in particular countries. After conducting the research study, it was revealed that all the ASEAN countries are supporting and implementing agricultural sectors as a main agenda in poverty eradication. The approach used by the government is realistic and practical. 
One of the approaches is the role played by the head of the people in the particular areas. For example, at Kampung Buntal, Sarawak the role played by the head is providing the wet market for the fishermen to sell their marine catch, so the people living in the area can survive. Moreover, according to Sarawak Minister of Modernization of Agriculture and Rural Economy, Datuk Amar Douglas Uggah Embas at the National Smallholders and Commodities Entrepreneurs Conference (NSCEC) 2015, rural areas can be transformed through agriculture development to assist the community there to get out of poverty and the low-income trap. 'These transformations will enable rural folks to earn more and help the Penans escape from the clutches of poverty. This situation will lead to the growth of the economy and slowly increase the purchasing power of people in rural areas and reduce the poverty rate. 'We in ASEAN have enjoyed not only peace and stability but have also witnessed an era of strong economic growth throughout the region' said Malaysian Prime Minister, Tun Dr. Mahathir Bin Mohammad during Reflection on ASEAN, 2004. Most importantly, the approach taken must be realistic, so that all the government will implement the same planning and ways to reduce poverty issues and increase more development in rural areas. It is indeed the One Vision, One Identity, One Community motto.

\section{Discussion}

The findings of this study indicate that the ASEAN Community is working together in eradicating the poverty in the country. The agricultural effort is believed to be one of the ways that was found efficient in reducing the poverty level. Moreover, the planning outlined in the ASCC 2025 did mention its benefits and how it engages the people. It touches all the people in a holistic way. Not only for the people but also for the culture, beliefs, dreams, language and etc. It is clearly stated in the ASCC Planning that the main focus is sustainability, inclusivity and resilience. Each of the focus has a realistic approach and effort that can be put into action.

Rural development is also implemented well by the government. The people representative or head plays an important role in rural development because all the complaints and demands made are reported to the head. The head becomes the liaison between the people and government. So the development highly depends on the role played by the government. Southeast Asia cannot be enduring security community or an effective economic community. Indeed, it cannot be an ASEAN Community in its truest and deepest sense-without being a socio-cultural community (Rodolfo, 2006).

Lastly, the planning and effort in rural development and poverty eradication are well planned and cooperation is given actively by the ASEAN members for each other. They are responsive towards the issues that raised by the community members and are given immediate solutions. Again, the approach outlined in the ASCC 2025 that focuses on sustainability, inclusiveness and resilience is holistically practical. Aspiring to a greater notion of social integration will help transform the domestic political agenda and build on the achievement of the ASCC which should be a key force (Maramis, 2017).

The strength of the study firstly shows that sustainable development, resilience and inclusivity have positively impacted the planning of ASEAN Socio Cultural Community to increase the level of rural development and agenda to eradicate poverty. Each of the approach has its own agenda and focus to be implemented. Secondly, ASEAN countries are highly committed in agricultural sector to help the poor and the needs of its people. Agricultural sector is nurtured by given fruit seeds, fertilizer, and even programmes to help the people in rural areas. These research papers have strong evidence to support each of the main points. However, the weakness of this paper was it didn't mention the exact year the event occurred in the areas. Thus, the research only focussed on 10 countries in ASEAN instead of a single idea from outside of ASEAN. For example, the involvement of an economic agenda from Europe at ASEAN community.

\section{Conclusion}

It clearly shows that people are impacted by the ASEAN Community planning. Three key factors in ASCC highlighted sustainability, resilience and inclusivity being used by ASEAN community as an approach to make the 'people-centricity' vision a reality. Implementation is the only action that can make any approach and effort become reality. Smart strategy is worthless if not implemented (Bruce, 2016). Increased development has impacted the level of poverty specifically in the rural areas. The government in ASEAN countries are putting agriculture as the main core of the planning in the poverty eradication matter.

Based on this research, it is highly recommended that governments should be strict in rural development implementation especially when the budget has been allocated to raise the development. There a lot of rural areas that still do not have accommodation and are poor. A second recommendation is to plan more entrepreneurship programs to help the rural people to sell their agricultural product and marine catches. At the same time this will increase the income and purchasing power. The third recommendation is to develop a more realistic universal approach that suits all ages by respecting the differences in all ASEAN countries. Thus, the ASEAN countries have high potential to be successful because of its uniqueness, in terms of being multicultural, and strong determination to help its people. 


\section{References}

Acciona. (n.d.). Sustainable Development. Retrieved from Acciona, Business as Unusualhttps://www.acciona.com/sustainable-development/\#

ADB, A. I. (2006). Indonesia Strategic Vision for Agriculture and Rural Development. 3.

Bernama. (2017). Malaysia urges for Asean poverty reduction to single-digit rate by 2025. Kuala Lumpur: the Sun Daily.

Bowen, G. A. (2009). Document analysis as a qualitative research method. Qualitative Research Journal, 27.

Caballero-Anthony, M. (2005). Understanding Development Gaps in ASEAN. IDSS Commentaries, 1-3.

Cirt. (n.d.). R Observational Method. Retrieved from Center for Innovation in Research and Teaching: https://cirt.gcu.edu

Foundation, R. W. (2008). Observation. Qualitative Research Guidelines project.

H. E. Mr.Rodolfo C. Severino, S.-G. (2001, February 6-7). ASEAN: Building The Peace in Southeast Asia. Association of Southeast Asian Nation.

Maramis, L. (2017). Buidling Asean Socio-Cultural Community \& Nation Building . Retrieved from United Nations Economic and Social Commission for Asia and the Pacific: https://pidswebs.pids.gov.ph/CDN/EVENTS/maramis_asean_sociocultural_community_(road_traversed_and_journey_ahead)_revised_21-8-2017.pdf

Mohamad, M. (2004). Reflections on Asean. Putrajaya, Malaysia: Pelanduk Publications (M) Sdn Bhd.

Nation, U. (2015). Sustainable Development Goals, 17 Goals to Transform Our World. Retrieved from United Nation, Sustainable Development Goals: https://sustainabledevelopment.un.org/?menu=1300

Secretarial, T. A. (2017). Asean Framework Action Plan on Rural Development And Poverty Eradication 2016-2020. asean.org.

Secretariat, A. (2015). Asean Community. Fact Sheet- Asean Community, 1-4.

Secretariat, T. A. (2016). Asean Socio-Cultural Community Blueprint 2025. The Association of Southest Asia Nations (ASEAN), 10-13.

Severino, R. C. (2006). Southest Asia in Search of an Asean Community. Singapore: ISEAS Publishing.

Simon H. Olsen, S. T. (2015). ASEAN Community and the Sustainable Development Goals: Positioning Sustainability at the Heart of Regional Integration. Researchgate.

V.Paramasivm. (2018). Op.Ed: Why Malaysia is leading the way in Asean for poverty eradication. Asian Corresspondent.

Workshop:Combodia, N. I. (2017). Agricultural Transformation and Market Integration in the Asia Region: Responding to Food Insecurity and Inclusiveness Concerns. Workshop Proceedings. Phnom-Pehn, Combodia: ATMI Combodia. 